\title{
STRATEGI PENGENDALIAN POLA PERGERAKAN DAN PENGGUNAAN LAHAN BERBASIS KONSEP COMPACT CITY DI KECAMATAN RAPPOCINI KOTA MAKASSAR
}

\author{
Andi Muhammad Akbar ${ }^{1}$ \\ ${ }^{1}$ Program Studi Arsitektur Universitas Muslim Indonesia
}

\begin{abstract}
Abstrak
Fenomena Urban Sprawl yang terjadi di Kota Makassar telah menimbulkan berbagai permasalahan, terutama di sektor transportasi salah satunya dapat dilihat melalui tingginya volume transportasi dari wilayah suburban menuju pusat Kota Makassar maupun sebaliknya, hal ini cenderung menyebabkan kemacetan dibeberapa titik di Kota Makassar. Untuk itu, sebagai alternatif utama pengimplementasian pembangunan berkelanjutan dalam sebuah kota dan sebagai solusi dari fenomena Urban Sprawl maka dicetuskanlah konsep kota kompak atau Compact City. Tujuan yang ingin dicapai dalam penelitian ini adalah mengkaji potensi penerapan konsep kota kompak di wilayah suburban Kota Makassar sebagai solusi permasalahan urban sprawl. Potensi penerapan ini ditinjau dari aspek kondisi wilayah suburban berdasarkan Indikator compact city, selanjutnya analisis pada aspek transportasi dengan manganalisis pola pergerakan penduduk dan kemudian menyusun strategi penataan kota dengan pendekatan konsep kota kompak (Compact City). Penelitian ini bersifat deskriptif, yaitu dengan menjelaskan kondisi wilayah suburban berdasarkan indikator compact city, selanjutnya menganalisis pola pergerakan penduduk dengan mengumpulkan data melalui observasi dan wawancara terhadap 321 responden. Data dianalisis dengan menggunakan matriks asal tujuan (MAT), deskriptif kuantitatif, dan analisis spasial dengan peta citra satelit, kemudian menyusun strategi penataan kota dengan pendekatan konsep kota kompak dengan analisis SWOT. Hasil penelitian menunjukkan bahwa konsep ini dianggap telah sesuai, hal ini berdasarkan pengukuran jarak tempuh penduduk dalam radius berjalan kaki dan bersepeda, dengan menggunakan instrumen penyebaran penduduk terhadap jarak tempuh dari konsentrasi penyebaran penduduk ke pusat aktifitas dengan fasilitas campuran di dalam wilayah penelitian. Sedangkan analisis pola pergerakan penduduk di wilayah Suburban berdasarkan tujuan pergerakan, kedakatan jarak menunjukkan bahwa pola pergerakan penduduk dari Suburban ke Urban umumnya menggunakan kendaraan pribadi dengan tujuan bekerja, berbelanja, rekreasi dan kegiatan sosial, sedangkan kegiatan pendidikan umumnya dilakukan di kawasan suburban. Selanjutnya berdasarkan hasil analisis sebelumnya dapat disusun beberapa strategi yang dapat mendukung pengimplementasian konsep kota dengan pendekatan konsep kota kompak (compact city).
\end{abstract}

Kata kunci: Konsep compact city solusi permasalahan urban sprawl.

\section{PENDAHULUAN}

Pertumbuhan penduduk dalam suatu wilayah perkotaan selalu diikuti oleh peningkatan kebutuhan ruang. Kota sebagai perwujudan geografis selalu mengalami perubahan dari waktu ke waktu. Kuantitas dan kualitas kegiatannya selalu meningkat sejalan dengan pertambahan penduduk perkotaan, sehingga ruang sebagai wadah kegiatan tersebut selalu meningkat sejalan dengan pertambahan penduduk perkotaan.

Kecepatan pertumbuhan penduduk perkotaan dipengaruhi oleh pola pembangunan terpusat di kota-kota besar. Selama pertumbuhan ekonomi sebagai poros pembangunan, akan terjadi pemusatan kegiatan ekonomi di wilayah perkotaan. Infrastruktur kota yang lebih baik dengan hadirnya jalan tol, bandar udara, terminal angkutan dalam dan luar kota, pusat pertokoan dilengkapi oleh fasilitas umum telah menimbulkan daya tarik tersendiri. Sehingga kota-kota besar secara terus menerus mengalami tekanan pertambahan penduduk yang terus membesar, dengan arus urbanisasi yang semakin besar.

2. Arus urbanisasi yang ekstrim, distribusi spasial dan permukiman yang timpang, inefisiensi infrastruktur perkotaan, sistem transportasi kota yang seadanya, gaya hidup berkendaraan yang eksesif dan boros energi sampai alpanya kota menyediakan ruangruang pejalan kaki yang nyaman adalah rutinitas masalah kota-kota metropolitan di Indonesia. Dampak dari perkembangan perkotaan yang tumbuh secara acak dan menyebar yang diistilahkan dengan fenomena urban sprawl yang diindikasikan telah terjadi di Kota Makassar dapat dilihat melalui tingginya volume transportasi dari wilayahsuburban menuju pusat Kota Makassar maupun sebaliknya, yang cenderung menyebabkan kemacetan di beberapa titik di Kota Makassar.

Terjadinya fenomena urban sprawl yang membawa berbagai dampak turunan negatif seperti meningkatnya angka pencemaran udara sebagai akibat semakin tingginya penggunaan alat 
transportasi telah menunjukkan pembangunan yang terjadi di Kota Makassar tidak berkelanjutan. Sebagai solusi dari fenomena urban sprawl yang terjadi di hampir seluruh kota di dunia dicetuskan konsep kota kompak atau compact city yang pada saat ini telah diyakini sebagai alternatif utama implementasi pambangunan berkelanjutan dalam sebuah kota dan konsep ini juga merupakan solusi untuk menjawab berbagai permasalahan perkotaan baik dari aspek tata ruang kota maupun dari aspek transportasi.

Kota kompak yang dimaksud adalah bentuk kota yang mengedepankan aspek kepadatan yang tinggi dan penggunaan lahan campuran serta dilengkapi dengan fasilitas transpotasi umum yang memadai. Namun, untuk menerapkan konsep ini di kota-kota di negara berkembang perlu dilakukan kajian lebih lanjut. Beberapa wilayah suburban di Kota Makassar telah menunjukkan tingkat kekompakan berdasarkan indikator compact city, seperti aspek kepadatan penduduk dan kepadatan bangunan serta penyebaran fasilitas dengan fungsi campuran yang relatif dekat dalam satu kawasan, namun mobilisasi penduduk yang tinggi dengan jarak yang jauh tetap terjadi di Kota Makassar. Terlebih lagi belum terdapat kajian mengenai strategi penataan kota yang dapat digunakan untuk mendukung penerapan konsep kota kompakyang dapat diterapkan untuk mereduksi pergerakan penduduk di Kota Makassar.

\section{ISI PENELITIAN}

\section{A. Jenis Penelitian}

Jenis penelitian yang dilakukan adalah tergolong penelitian non eksperimental dan bersifat deskriptif, mengkaji potensi penerapan konsep compact city pada wilayah suburban yang memiliki tingkat kekompakan kota berdasarkan indikator compact city di kota Makassar.

\section{B. Lokasi dan Waktu Penelitian}

Lokasi penelitian ini difokuskan pada wilayah suburban yang telah mengalami permasalahan urban sprawl tetapi pola perkembangan kotanya berlangsung secara sporadis dengan kelompok konsentris yang besar. Dasar pertimbangan penentuan kawasan tersebut adalah tingginya pertumbuhan penduduk, tingginya pemanfaatan lahan dan tingginya pergerakan penduduk, indikator yang dapat dililhat secara nyata adalah pencampuran guna lahan seperti pemukiman (perumahan), perdagangan (retail dan ruko), pendidikan dan kesehatan. Berdasarkan hal tersebut maka lokasi penelitian ditetapkan pada wilayah Kecamatan Rappocini dan difokuskan pada lima kelurahan yang saling terintegrasi menuju kewilayah suburban . Kelima kelurahan tersebut masing-masing adalah Kelurahan Gunung Sari, Kelurahan Tidung, Kelurahan Mappala,Kelurahan Karunrung dan Kelurahan Kassi-kassi. Berdasarkan letak geografi lokasi penelitian ini berbatasan dengan Jalan A.P. Pettarani, Jalan Hertasning, Jalan Arupala, Jalan
Syech Yusuf dan Jalan Sultan Alauddin. Kelima jalan tersebut salaing terhubung. Penelitian ini berlangsung selama \pm 3 bulan, yaitu januari-maret 2015.

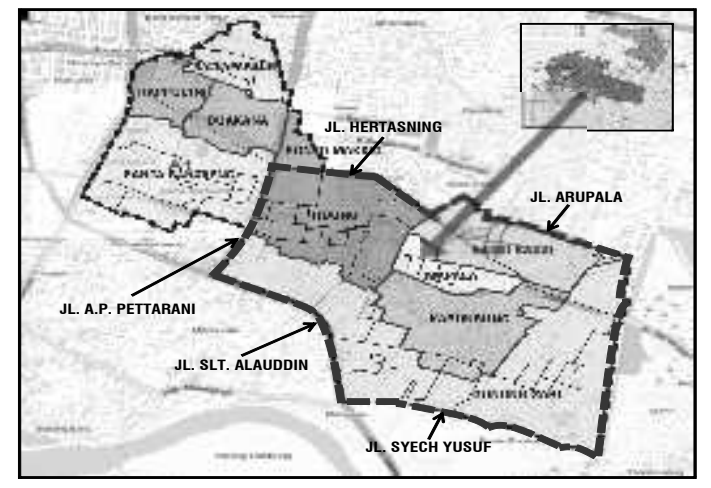

Gambar 1. Peta Situasi Penelitian

\section{Populasi dan Sampel}

Populasi dalam penelitian ini adalah seluruh penduduk yang tinggal di wilayah penelitian utamanya perumahan permukiman yang dibangun secara massal di kawasan yang terindikasi memiliki tingkat kekompakan kota yang tinggi. Sampel adalah kepala keluarga yang tinggal pada perumahan yang dibangun secara massal di wilayah penelitian. Metode penarikan sampel dilakukan secara acak dan berdasarkan kelompok (Cluster sampling). Tahap pertama yaitu membuat cluster populasi (segmen) beradasarkan kedekatan jarak, aksesibilitas dan guna lahan (Perumahan, pendidikan, perdagangan dan industri) disekitarnya.

\section{Jenis dan Sumber Data}

Data yang diperlukan dalam penelitian ini adalah data primer melalui kombinasi antara metode survey, observasi, interview/wawancara dan data sekunder yang menggunakan studi kepustakaan yang berkaitan dengan rumusan masalah. Data ini dapat diperoleh dari beberapa instansi terkait diantaranya Dinas Pekerjaan Umum Kota Makassar,Dinas Tata Ruang Kota Makassar, Dinas Perhubungan Kota Makassar, Kantor Kecamatan Rappocini, Kantor BPS Kota Makassar,DPD REI Sulsel, DPC Organda Kota Makassar dan sebagainya.

\section{E. Teknik Pengumpulan Data}

Teknik pengumpulan data yang digunakan dalam penelitian ini, adalah sebagai berikut: (1). Observasi, yaitu melakukan pengamatan langsung pada objek penelitian. (2). Interview (Wawancara), yaitu pengumpulan data primer untuk memperoleh informasi secara sistematis dengan menggunakan kuisioner Pertanyaan dalam kusioner disusun secara terstruktur serta melakukan wawancara langsung terhadap sejumlah responden guna memperoleh data yang dibutuhkan dan berkaitan dengan kegiatan penelitian. (3). Studi dokumentasi, yaitu dengan 
memepelajari dokumen-dokumen dari berbagai laporan yang berhubungan dengan permasalahan penelitian.

\section{F. Teknik Analisis Data}

Data-data yang ada diproses melalui pengelompokkan data, klasifikasi menurut urutan permasalahan dan klasifikasi faktor-faktor internal dan eksternal. Setelah itu melakukan penyusunan strategi dengan menggunakan analisis SWOT, Semua elemen dalam SWOT akan dijaring melalui jawaban responden terhadap pertanyaan yang diajukan. Analisis SWOT digunakan untuk mengidentifikasi dan merumuskan suatu strategi.

\section{PEMBAHASAN}

Pada penelitian ini memperlihatkan bahwa Indikator-indikator yang dapat digunakan untuk mengukur compactness dalam konsep compact city dapat dikelompokkan dalam tiga dimensi / aspek yaitu kepadatan, fungsi campuran, dan intensifikasi. Aspek kepadatan berkaitan dengan tingkat kepadatan penduduk, , kepadatan terbangun, dan kepadatan perumahan. Aspek fungsi campuran terkait dengan penyediaan fasilitas, sebaran horizontal fasilitas, perubahan guna lahan dan guna lahan campuran. Sedangkan aspek intensifikasi meliputi tingkat pertumbuhan penduduk, pertumbuhan pembangunan, pertumbuhan kepadatan.

Salah satu aspek yang berperan untuk mengetahui tingkat kekompakan kota adalah aspek kepadatan penduduk. Hal ini penting mengingat kepadatan dalam perspektif konsep kota kompak adalah indikator utama pengimplementasian konsep ini. Berdasarkan Buku Makassar Dalam Angka tahun 2011, penyebaran penduduk Kota Makassar jika dirinci menurut kecamatan menunjukkan bahwa penduduk masih terkonsentrasi diwilayah kecamatan Tamalate, yaitu sebanyak 170.878 atau sekitar 12,76 persen dari total penduduk, disusul kecamatan Rappocini sebanyak 151.091 jiwa atau sekitar 11,28 persen dengan kepadatan penduduk sebesar 16.370 jiwa/km2 atau $163 \mathrm{jiwa} / \mathrm{ha}$.

Dalam hal kepadatan penduduk ini instrumen yang dipakai untuk mengukur potensi penerapan konsep compact city pada wilayah suburban yang diamati adalah aspek penyebaran penduduknya. Dari hasil pengamatan dan tabel kepadatan penduduk, konsentrasi penyebaran penduduk terbesar terjadi di Kelurahan Gunung Sari, mengingat wilayah ini masih merupakan daerah terbuka, sementara berdasarkan pengamatan pusat kegiatan dengan fungsi campuran yang ada di wilayah Kecamatan Rappocini yaitu terletak di Kelurahan Tidung.

Kota kompak atau padat ( Compact City ) sebagai sebuah ide atau konsep yang dianggap paling berkelanjutan dan anti urban sprawl. Pilihan kompak atau tidak kompak dalam menjawab masalah keberlanjutan sebuah kota sebenarnya sangat bergantung pada kecendrungan perilaku, kapasitas, fleksibilitas dan kebijakan, (Trimadi. H. 2005). Hal yang kiranya cukup penting adalah mengkaji optimalisasi tingkat kekompakan kota dalam menjawab tantangan ini.

Beberapa peneliti telah menjadikan tema kota kompak (Compact City) dalam pembahasan mereka. Penelitian tentang konsep ini telah dilakukan oleh Barret menyatakan dalam surveinya mengenai tingkat kota yang padat sebagai salah satu dimensi dari konsep Compact City terhadap transportasi di Inggris, bahwa semakin tinggi tingkat kota yang padat maka semakin kecil jumlah pergerakan dan semakin banyak penggunaan kendaraan umum atau berjalan kaki. Dari hasil penelitiannya didapatkan bahwa kawasan yang paling padat, memiliki jumlah pergerakan yang mencapai $37,37 \%$ lebih sedikit dari jumlah pergerakan pada kawasan dengan kepadatan rendah, dengan total pergerakan pada kawasan tersebut adalah $192,2 \mathrm{~km}$ per orang per minggu atau rata rata $27,475 \mathrm{~km} /$ hari.

Pada penelitian Sadikin dilaksanakan dengan cara mengidentifikasi dan mensimulasi penataan pelayanan pendidikan pada jenjang SMP berdasarkan indikator Compact City di kota Surabaya. Pengukuran compactness sebagai indikator keberlangsungan kota di wilayah metropolitan Bandung. Bentuk dan Pengembangan Kawasan Perkotaan Berkelanjutan ( Kajian Potensi Kompaksi Perkotaan di Kawasan Perkotaan Bandung ), (Penalosa, E. 2005). Tujuan penelitian ini adalah untuk menganalisis keterkaitan antara bentuk perkotaan dan kebelanjutan sebagai landasan untuk mengintervensi terhadap struktur dan pola ruang kawasan perkotaan dan merumuskan arahan pengembangan kawasan perkotaan secara spasial untuk mewujudkan struktur dan pola ruang kawasan perkotaan yang lebih berkelanjutan, (Tamin. O.Z. 2000). Berdasarkan hasil analisis disimpulkan bahwa bentuk perkotaan berpengaruh terhadap keberlanjutan perkotaan, baik secara lingkungan, sosial, maupun ekonomi.

Wibawa, (2009) dalam penelitiannya berjudul Identifikasi Urban Compactness di Wilayah Metropolitan Semarang. Tujuan dari penelitian ini adalah mengidentifikasi pola spasial urban compactness di wilayah studi. Tujuan tersebut akan dicapai dengan mengidentifikasi indikator compact city berdasarkan konsep dan prinsip keberlanjutan kota, menganalisis struktur dan pola ruang, menganalisis tipologi kecamatan dan menganalisis keterkaitan urban compactness dengan transportasi di wilayah studi.

\section{HASIL}

Berdasarkan Perda Kota Makassar Tahun 2005 tentang Rencana Tata Ruang Kota Makassar 2005-2015 Kecamatan Rappocini merupakan 
Kawasan Permukiman Terpadu. Misi Kawasan Permukiman Terpadu adalah mewujudkan dan mengembangkan kawasan pemukiman yang berkepadatan sedang dan tinggi ke arah Timur Kota serta mengendalikan kegiatan Jasa dan Niaga yang melebihi kebutuhan kawasan. Untuk itu Kecamatan Rappocini ini diarahkan pada pengembangan fungsi kawasan berbasis pengembangan infrastruktur yang meliputi : Pengembangkan kawasan permukiman baru terutama di wilayah bagian Timur Kota (antara jalan lingkar tengah dan luar); Mendorong pengembangan kawasan permukiman $\mathrm{KDB}$ rendah beserta fasilitasnya di daerah pengembangan permukiman Panakkukang Mas; Mempertahankan lingkungan permukiman yang teratur, yang tersebar dalam kelompok-kelompok perumahan berkompleks didalam kawasan; Mempertahankan fungsi perumahan pada kawasan mantap; Melengkapi fasilitas umum di kawasan permukiman; Membatasi perubahan fungsi kawasan permukiman yang sudah ada dan sekaligus melestarikan lingkungannya. Dari data yang ada terkait permohonan perizinan membangun yang tinggi pada Kec. Rappocini dan kenyataan yang ada berdasarkan pengamatan menunjukkan bahwa luas area terbangun semakin tinggi.

Berdasarkan Rencana Tata Ruang Kota Makassar 2005-2015, rencana pengembangan infrastruktur di Kota Makassar antara lain pelebaran jalan, pembangunan jalan lingkar tengah (middle ring road) dan jalan lingkar luar (outer ringroad) yang menghubungkan kawasan suburban dan sisi selatan Kota Makassar, peningkatan kualitas angkutan umum dengan penerapan Bus Rapid Transit (BRT).

Untuk infrasruktur khususnya jaringan jalan, terbukanya akses ke timur Kota Makassar yakni poros Jl. Hertasning baru menuju kawasan baru Pattallassang Kab. Gowa yang menyebabkan berkembangnya perumahan landed yang mengindikasikan terjadinya urban sprawl dikawasan suburban ini. Rencana pengembangan kota metropolitan Mamminasata, dengan luas wilayah \pm 2.473 dan jumlah penduduk 2 juta jiwa yang diproyeksikan berjumlah 2,9 juta pada 2020; serta rencana pengembangan kawasan industri terpadu dikawasan Pattalassang Kab. Gowa akan mendorong perkembangan permukiman disekitarnya. Jika tidak didukung dengan pengembangan pusat-pusat kegiatan disekitarnya dan pembangunan infrastruktur, khususnya transportasi dikhawatirkan akan berdampak pada tingginya kepadatan lalu lintas menuju pusat Kota Makassar.

Dalam mengantisipasi permintaan perjalanan (trip) penduduk Kota Makassar dalam 10 tahun terakhir ini, studi JICA tahun 1989 telah merekomendasikan pembangunan 3 (tiga) jalan lingkar (ring road) untuk menghubungkan jalanjalan radial tersebut, yaitu : (a). Jalan Lingkar Dalam (Inner Ring Road), menghubungkan ruas jalan
A.P.Pettarani - Pelabuhan Makassar. (b). Jalan Lingkar Tengah (Middle Ring RoadO, menghubungkan ruas Jl. Syech Yusuf - Daerah Kampus Unhas). (c). Jalan Lingkar Luar (Outer Ring Road), menghubungkan Kota Maros dan Kota Sungguminasa.

\section{KESIMPULAN}

Kondisi kota di wilayah suburban Kota Makassar berdasarkan indikator konsep compact city seperti kepadatan penduduk, kepadatan bangunan, dan sebaran fasilitas dengan fungsi campuran, telah menunjukkan bahwa potensi penataan kota dengan pendekatan konsep kota kompak di wilayah suburban dapat dilakukan atau telah sesuai dengan arahan dalam konsep tersebut. Adapun instrumen yang dipakai untuk mengukur kesesuaian tersebut adalah aspek penyebaran penduduk dan jarak tempuh penduduk ke pusat kegiatan dalam lingkup Kecamatan Rappocini sebagai wilayah penelitian. Diketahui bahwa kegiatan dengan fungsi campuran dalam wilayah ini terpusat di Kelurahan Tidung dan konsentrasi penyebaran penduduk lebih banyak terjadi di Kelurahan Gunung Sari. Hasil analisis dengan menggunakan instrumen tersebut menunjukkan bahwa jarak tempuh antara pusat kegiaatan dengan konsentrasi penyebaran penduduk masih dalam radius berjalan kaki dan bersepeda sehingga potensi penerapan konsep ini dianggap sesuai. Berdasarkan hasil penelitian ini, maka terdapat beberapa saran dan kemungkinan pengembangan penelitian lebih lanjut, yaitu Kondisi tingkat urban compactness yang tinggi perlu disebar dan tidak hanya terfokus pada pusat Kota Makassar seperti yang terjadi pada pada saat ini. Kawasan dengan tingkat urban compactness yang tinggi setidaknya terdapat pada setiap kecamatan yang dapat dengan mudah dicapai dengan jari-jari 20 atau 30 menit berjalan kaki dari kawasan sekelilingnya. Kondisi kota dengan pola yang compact yang hanya terdapat di satu titik, sebenarnya merupakan kondisi yang sprawl, karena hanya terdapat satu pusat sedangkan kawasan lainnya bermobilisasi ke titik tersebut. Untuk mencegah hal ini, pola kawasan sebaiknya menggunakan lebih banyak titik sub-city center.

\section{DAFTAR PUSTAKA}

- Akhmad, (2010), Kinerja Ruas Jalan Arteri di Kota Makassar, Program Pascasarjana, Universitas Hasanuddin, Makassar

- Cendrawati, A, (2009), Penetuan Halte Angkutan Kota pada Rute Terminal Regional Daya-P.T. Telkom di Kota Makassar, Program Pascasarjana, Universitas Hasanuddin, Makassar.

- Jinca. (2006). Rencana tata ruang terpadu untuk wilayah metropolitan Mamminasata. KRI International Corp Nippon Koei Co.Ltd 
- Khisty, J dan Lall, K. (2006). Dasar-dasar rekayasa transportasi, karakteristik, teori dan kebijakan. Ghalia Indonesia, Jakarta

- Penalosa, E. (2005). Peran Transportasi dalam Kebijakan Perkembangan Perkotaan, Modul 1a, Transportasi Berkelanjutan: Panduan Bagi Pembuat Kebijakan di Kota-Kota Berkembang. GTZ. Germany

- Soemardjito, J dkk. (2009), Respon Masyarakat terhadap Pengembangan Fasilitas Park and Ride untuk Mendukung Angkutan Umum Perkotaan. Proceeding: Simposium XII Forum Studi Transportasi Antar Perguruan Tinggi, Universitas Kristen Petra, Surabaya

- Sukarto, H. (2006), Transportasi Perkotaan dan Lingkungan. Jurnal Teknik Sipil vol 3 no 2. Universitas Pelita Harapan, Banten.

- Takeda, H dkk. (2010). Analysis of Public Transportation Use Based on The Person Trip Survey and Exammination of Strategy of TOD. Proceedings: The 7th International Symposium on City Planning and Environmental Management in Asian Countries. Asian Urban Research Group (AURG).Fukuoka, Japan.

- Tamin. O.Z. (2000). Perencanaan dan Permodelan Transportasi. Edisi kedua. ITB, Bandung

- Trimadi. H. (2005). Transit Oriented Development (TOD) sebagai Bagian Transport Demand Management (TDM), Seksi Lalu Lintas Perkotaan Wilayah II Subdit Lalu Lintas Perkotaan, dit bstp. www.hubdat.web.id/pustaka/ensiklopedia/bstp/t odtdm.pdf diunduh 2 Maret 2009.

- Wibawa, A Bayu, (2009). Tata Guna Lahan dan Transportasi dalam Pembangunan yang Berkelanjutan, www.pustralugm.org/dpr/BK/ Interaksi Transportasi dan Guna Lahan.pdf, diakses tanggal 4 juli 2009 pukul 10.54 WiTa 